\title{
ФІЛОСОФСЬКІ ПОГЛЯДИ А.В. ЛУНАЧАРСЬКОГО НА СУСПІЛЬНІ ПРІОРИТЕТИ В УМОВАХ КУЛЬТУРНИХ ТРАНСФОРМАЦЙ ПЕРШОЇ ПОЛОВИНИ ХХ СТОЛІТТЯ
}

\author{
І.Г. Мухіна, кандидат історичних наук, доцент ХІФ КНТЕУ
}

У науковій статті здійснено аналіз філософських поглядів А.В. Луначарського щуодо важливих суспільних пріоритетів, які виникають в умовах культурних трансформачій першої половини ХХ століття на прикладі сочіального експерименту більшовиків під час «культурної револючії» та в період створення так званого «пролетарського» суспільства. Теоретик вважав, що пролетаріат у процесі історичної спадковості та при переході до соџіалістичної культури має відігравати виключну й авангардну роль й бути законним спадкоємием не тільки виробничих сил, створених у надрах буржуазного суспільства, але й спадкоємщем усіх матеріальних та культурних иінностей.

Доведено, щзо зміст й сутність культурних трансформаџій під час становлення сочіалістичного суспільства сприяв формуванню тоталітаризму на підгрунті соціальних міфрів та револючійної романтики. У цілому, через призму філософських міркувань А.В. Луначарського щุодо впливу культурних трансформацій на иіннісні пріоритети суспільства, ми можемо побачити спроби більшовиків створити корпоративну систему на соиіалістичних засадах, у якій велика увага приділялася культурній та ідеологічній сферам, без яких неможливо було створити дієві механізми для керування й управління суспільством та виробити сочіальний міф про комуністичне суспільство як духовний орієнтир людства.

Акиентується увага на тому, щуо так звана "револючійна романтика», яка була притаманна багатьом радянським теоретикам першої половини XX століття, по суті виправдовувала будь-які засоби насилля й примусу людини у культурній та ідеологічній сферах заради формування щзасливого майбутнього, иілеспрямовувала неухильно рухатися у фарватері політичних установок й директив влади. Доведено, щуо елементи диктатури пролетаріату, які розглядалися як тимчасові міри, по суті поступово стали перманентними основами формування тоталітаризму.

Ключові слова: культурна револючія, культурна спадщина, цінності, культура, мистецтво, колективізм, особистість

Постановка проблеми. У сучасну добу людська цивілізація переживає глибоку духовну кризу, пов'язану з тим, що сучасний науково-технічний прогрес, на жаль, не вирішує глобальні проблеми людства й не може у другій половині XX століття розглядатися як головний шлях до щасливого майбутього й регулятор усіх економічних трансформацій. Духовна сфера, у якій формуються ціннісні орієнтири, ментальність і життєспроможність людини стають настільки актуальними, що знову ми повертаємось до культурної спадщини минулих поколінь, аналізуємо ті способи й (อ) Мухіна І.Г., 2019, http://doi.org/10.34142/23131675.2019.52.11 
інструменти, які наші предки обирали для вирішення ключових проблем. Суспільна практика останніх двох десятиліть, що була спрямована на беззаперечне відкидання ціннісного досвіду, накопиченого десятками поколінь у радянський період, не дозволяє на сьогодні вирішити ряд важливих питань щодо консолідації суспільства. Тому актуальності набуває проблема глибокого переосмислення соціально-культурних, ментальних, політико-ідеологічних основ формування соціалістичного суспільства, за рахунок яких вдалося створити консолідоване суспільство, цілеспрямоване на будівництво й розвиток держави. У цьому контексті певну цінність представляє філософська спадщина одного з відомих радянських теоретиків першої половини XX століття А.В. Луначарського, який пильну увагу приділяв суспільним пріоритетам, які мають бути сформовані в умовах серйозних культурних трансформацій та сприяти формуванню консолідованного суспільства. Цей аналіз надає можливість зрозуміти логіку культурних перетворень, які змінили ціннісні аспекти суспільства, побачити помилки, які привели до зародження тоталітаризму. Виходячи 3 цього, авторка ставить перед собою мету - здійснити аналіз філософських міркувань А.В. Луначарського й виділити головні суспільні пріоритети, які визначали зміст й сутність культурних трансформацій, вплинули на становлення соціалістичного суспільства, сприяли формуванню тоталітаризму на підгрунті соціальних міфів та революційної романтики.

Основний виклад матеріалу. Після повалення російського самодержавства під проводом більшовиків розгортається перша хвиля так званої «культурної революції». Перший культурний потік представляли теоретики так званого «більшовицького» гатунку А. Луначарський, М. Бухарін, Я.Ряппо, Н. Крупська, А. Богданов та інші. На перший план вони висувають ідею створення нової «пролетарської культури», знищення традиційного культурного укладу буржуазного суспільства та встановлення ідеологічного контролю над усіма культурними перетвореннями. Практичне втілення цих ідей привело до нівелювання особистості як індивідуальної, 
унікальної істоти 3 власним світобаченням й світорозумінням. Примат загального над індивідуальним привело до примусу й насилля над світоглядом та духовним світом людини. Але намагання влади прискорити усі суспільні перетворення та знищити плюралізм думок породжували масу ухилів й помилок, вносили елементи деспотії по відношенню до усіх «непролетарських» класів. У цих умовах освіта й культура виступають основним ідеологічним знаряддям усіх революційних змін, а їхні функції відповідають загальнодержавним цілям. У цілому, радянська ідеологія, яка формувалася у 20-х рр. XX століття в умовах політичної та міжнародної ізоляції, потребувала іманентного самообертання, самопізнання, самообгрунтування та самооновлення, що відбилося у методологічних та ідеологічних установках щодо створення єдиної концепції виховання й освіти підростаючого покоління та підготовки його до суспільної життєдіяльності.

Так, А.В. Луначарський велике значення у освітньо-виховному процесі приділяв пролетарській культурі й мистецтву, в яких найбільше проявляється ідеологія. Ним був розроблений принцип так званої наукової естетики та партійності мистецтва, що трактували розвиток культури й мистецтва 3 позицій ідеології та світогляду митця. Апелювання до того, що нова освіта й культура повинні бути безкласовими та гармонійними, по суті увійшло у протиріччя 3 необхідністю нової влади утримати своє панування шляхом насадження нової ідеології у суспільство. Це означало неможливість існування безкласового освітньо-культурного поля в умовах поширення марксистської ідеології та знищення буржуазних соціальних інститутів. Ліквідація будь-яких форм експлуатації та допущення народних мас до освіти - це були головні гасла усіх культурних перетворень у перші роки радянської влади, що мали місце у численних публікаціях, присвячених розвитку освіти та культури. Але за втіленням цих демократичних гасел у життя стояла необхідність нещадної боротьби 3 тими, хто не сприймав революційних перетворень, тому під культурними трансформаціями 
фактично відбувалося насильне насадження так званої пролетарської ідеології.

У праці «Марксизм и литература» А. Луначарський проаналізував вплив ідеології на культуру у цілому, зокрема, на образотворче мистецтво, живопис, літературу. Так, він пише: «Искусство с марксистской точки зрения может рассматриваться и как часть промышленности (как художественная промышленность),... и как идеология» [1, с. 175]. Теоретик схиляється до того, що у будь-яку історичну епоху мистецтво, а саме його зміст і форма, відображає ідеологію тих класів, які є творцями цього мистецтва. Він вважає, що ідеологічною стороною мистецтва є те, який об'єкт обирається з дійсності та яким чином він відображається через призму творчої душі митця. На його думку, особливо ідеологія проявляється у літературі, друкованому слові, тому що слово $є$ мовою інтелекту та емоцій. Будь-яка література, яка позбавлена змістовності, - це показник кризи та занепаду, спустошеності класів, які іï підтримують, Таким чином, А.Луначарський, схиляється до того, що культурна спадщина минулого є еволюцією поглядів, думок та ідеологічних установок тих класів, які іiі створювали у певних історичних умовах. Розмірковуючи над творчим потенціалом людини, теоретик вважає, що саме під час революційних процесів людина усвідомлює себе не «гвинтиком» у соціальному механізмі, а творцем, який має безкінечні здібності та прагне особистісного інтегрального розвитку. Але, на його думку, такий розвиток можливий лише у колективі, у суспільстві, перетвореному пролетаріатом. Особистість повинна прагнути до щастя, яке досягається лише у суспільній та колективній діяльності. Осмислюючи роль мистецтва як певної надбудови над виробничими взаємовідносинами, А.В. Луначарський розглядав його у двох відношеннях: як частину самої промисловості та як ідеологію, що системно відбиває у людській свідомості буття, наповнює собою свідоме життя людства. На думку теоретика, серед усіх ідеологій саме мистецтво є особливою формою пізнання дійсності. Зрозуміти мистецтво - це означає встановити до нього моральне й естетичне 
відношення. Таким чином, літературу й мистецтво А.В. Луначарський вважає віжливішою сферою суспільства, де найбільше проявляється ідеологія [2, с. 41].

Аналізуючи роль культури та мистецтва у побудові пролетарської держави, А. Луначарський відмічав, що у кожному з видів мистецтва так чи інакше присутня ідеологія. «То, какая именно действительность выбирается как объект, отражаемый искусством, и то, каким образом это отражение делается, какие претерпевает оно изменения, пройдя сквозь творческую душу художника, и является идеологической стороной искусства. Идеология, могущая быть высказанной словами, уложенной в понятия, здесь налицо и даже в значительной мере на первом плане». На думку теоретика, ідеологія найбільше проявляється саме у літературному мистецтві [3, с. 17].

У цілому проблема успадкування ціннісного досвіду попередніх поколінь розглядається через призму трактування буржуазної системи освіти як кріпацької, феодальної, авторитарної, яка придушує ініціативу, самодіяльність, унеможливлює колективну працю. Як один 3 перших народних комісарів просвіти А.В. Луначарський піддавав сумніву тезу щодо особистості як істинного творця культурних цінностей, як першопричини творчості, вважаючи це чисто містичним підходом, де індивідуальний дух був самостійним й незалежним початком. Спираючись на емпіричні ідеї Д. Локка, А. Луначарський схилявся до того, що людина це маленька tabula rasa (чистий аркуш), що поступово починає заповнюватися «письменами життя» $[3$, с. 6]. Народна освіта у буржуазному суспільстві, на його думку, зводилася до передавання певного рівня технічних знань й навичок, але у такому виді, щоб максимально вихолостити з людини здатність активно діяти й критично мислити. Тому, щоб оволодіти культурою, треба вилучити з неї усі «непотрібні» елементи та замінити їх такими, що дозволять усі знання та навички використати у боротьбі за ідеали революції [4, с. 53]. Більшовики розуміли, що повністю й швидко зламати старе культурне підгрунтя неможливо, тому демагогічно декламували, що як соціалістичне виробництво $\epsilon$ продуктом виробництва капіталістичного, так й поки що нова пролетарська 
культура $є$ гілкою великого дерева загальнолюдської культури. Так, B.I. Ленін стверджував: «Никогда никакое разрушение не доведет до того, чтобы культура исчезла совершенно. В той или иной своей части, в тех или иных материальных остатках эта культура неустранима» [5, т. 36, с. 46]. Але на відміну від старої культури нова соціалістична культура майбутнього розглядалася як безкласова, гармонійна, з власним змістом й відповідною формою. Але їй повинна передувати пролетарська культура як культура перехідного періоду, що має риси уособленості, класовості, спрямованості на нещадну боротьбу зі старим та ворожим. Одже, пролетарське мистецтво розглядалося як специфічне явище, націлене на організацію емоцій окремих осіб, груп, класів та цілих націй. А.В. Луначарський та його соратники вважали, що пролетаріат у процесі історичної спадковості та при переході до соціалістичної культури має відігравати виключну й авангардну роль й бути законним спадкоємцем не тільки виробничих сил, створених у надрах буржуазного суспільства, але й спадкоємцем усіх матеріальних та культурних цінностей. Крім того, залишки минулого у свідомості людей мали певну економічну основу для свого підживлення протягом довгого історичного часу, спиралися на звичні, взаємодіючі суспільно-економічні уклади. Тому викорінити відразу стару культурну спадщину неможливо, а треба з неї взяти тільки те, що буде відповідати ідеології нового суспільства [6, с. 11]. У контексті поставлених державних завдань щодо естетичного виховання молодого покоління. А.В.Луначарським були розроблені принципи побудови програми естетичного виховання, що включали до себе формування естетичних смаків шляхом безпосереднього залучення людини до мистецтва, філософської та загальної освіти, трудового та морального виховання. На його думку, виховний вплив мистецтва ефективний лише у випадку, коли особистість залучена у практично-перетворювальну діяльність $[7$, c. 15$]$.

А.В. Луначарський, висловлюючи своє відношення до ролі освіти у побудові соціалістичного суспільства, відмічав, що силою та примусом 
побудувати соціалізм неможливо. На його думку, тільки засобами освіти та культури можна корінним чином змінити психологію людей [8,c.34]. Осмислюючи цілі виховання у епоху панування диктатури пролетаріату, він розглядав дитину як «напівфабрикат», як сировину, яка не має завершеного образу, тому навчально-освітній процес він мислив як трудовий процес, результатом якого $є$ створення «нової» людини. Ставлячи під сумнів точку зору багатьох педагогів щодо виховання гармонійно розвинутої людини, він був впевнений, що виховати таку людину у суспільстві перехідного типу неможливо. Процес постійної боротьби не може бути гармонійною обстановкою у формуванні нової людини, бо гармонійна людина не може жити у негармонійному суспільстві. «Гармонійна» людина буде шокована від суспільних революційних процесів, буде прагнути залишити це суспільство. На думку А.В. Луначарського, особистість не може йти на боротьбу, на війну, маючи «толстовську миролюбність». Якщо суспільство не виховає людину, здатну боротися, революційно перетворювати суспільство, героїчно працювати 3 почуттям самовідданості й самопожертви, нехтуючи своїми особистими інтересами та бажаннями, то побудувати світле соціалістичне майбутне буде неможливо. «Мы гармонические цели предусматриваем, но в процессе борьбы надо быть иными. Надо различать социализм в процессе борьбы и социализм победивший. Социализм победивший - это бесклассовое общество, а социализм в процессе борьбы - это угнетенное человечество, которое рвет свои живые путы, состоящие из живых тел и живого самосознания его классовых врагов» $[9$, с. 443, 446].

Аналізуючи особистісні риси, які повинні бути виховані у «новій» людині, А.В. Луначарський наголошує, що колективіст живе суспільним життям більше, ніж особистими інтересами, він сповнений пафосом політико-економічних відносин соціалістичного будівництва, що сприймаються як сенс життя. Відстоюючи колективізм як основу комуністичного виховання, теоретик стверджує, що людина повинна мислити, як «ми», стати живим, корисним, відповідальним органом, частиною цього «ми». Але у той 
же час А. Луначарський застерігав від того, щоб це виховання не привело до появи «стадності», повного розчинення особистості, позбавлення оригінальності та індивідуальності людини. Протиставляючи колективну особистість «стадній», теоретик запевняе, що саме остання здібна підкорятися бонапартизму, вождізму, але не здібна до будь-якої критики дійсності. Тому внаслідок виховання у особистості повинні бути розвинуті індивідуальні особливості, таланти, доцільні навички, які людина у себе вбирає, й котрі суспільство їй пропонує [9, с. 443, 446].

Але створена А. Луначарським ілюзія щодо можливості виховання окремої унікальної особистості в умовах суцільного колективізму та політичних «вказівок» поступово розчиняється під впливом тоталітарної свідомості й тоталітарної ідеології, що невпинно встановлюється у радянському суспільстві. Критикуючи позицію М. Бердяєва, що марксизм вимагає знищення особистості у колективі, а колектив, виконуючи функцію бога, поглинає індивідуальність людини, теоретик стверджує, що тільки марксистськи спрямований колектив надає свободу суспільству [10, с. 160]. Розмірковуючи над революційними перетвореннями в усіх сферах суспільного життя, А.В. Луначарський говорить про появу людини «нової релігії», яка має бажання власного інтегрального розвитку, але це можливо лише у колективі, у пролетарському суспільстві. Досягнення щастя як найвищого ідеалу людського життя можливо лише у спільній, колективній діяльності, при соціалізмі, де людина людині є другом, де є радість й великі почуття [1, с. 175]. У своїх міркуваннях А.В. Луначарський доходить висновку, що у людині від народження закладена схильність до колективності. Так, у статті «Вопросы морали и Метерлинк» він писав, що поняття «ми» еволюційно народжується 3 природної родової групи та іiі співробітництва, що поступово модифікує іiї у сім’ю, плем’я, націю, людство, партію. Саме колективізм у тисячу разів збільшує палітру відчуттів, надає можливість радіти перемогам, у тому числі й перемогам минулих поколінь, які складали частину поняття «ми». Установку свідомості на те, що «я» 
знаходиться всередині «ми», А.В. Луначарський називає «макроскопічним індивідуалізмом та широкосердям», на відміну від традиційного індивідуалістичного егоїзму, який хоча й може бути розумним, але все ж таки є проявом «мікропсихіки та узкосердя». Теоретик прямо говорить про доцільність створення теорії «соціального міфу» у сфері пролетарської свідомості, схиляючись до того, що виховання колективності дозволяє людині будувати відносини 3 колективом та розвивати ці відносини через спільну працю у часі й просторі, через призму таких відчуттів, як радість, солідарність, справедливість. Саме за рахунок колективізму у новому суспільстві будуть вирішені проблеми загальнолюдської організації праці, як основи «істинної людської культури» [1, с. 175].

Висновки. У цілому, через призму філософських міркувань А.В. Луначарського щодо впливу культурних трансформацій на ціннісні пріоритети суспільства, ми можемо побачити спроби більшовиків створити корпоративну систему на соціалістичних засадах, у якій велика увага приділялася культурній та ідеологічній сферам, без яких неможливо було створити дієві механізми для керування й управління суспільством та виробити соціальний міф про комуністичне суспільство як духовний орієнтир людства. У цьому контексті колективізм став одним з духовних концептів культурної революції, через який здійснювався процес виховання народних мас у дусі марксизму. А.В. Луначарський доводив, що тільки через колективізм людина радянської формації має сприймати суспільні ідеали як свої власні, усвідомлювати істинність й закономірність обраного суспільством шляху до досягнення ідеального та щасливого майбутнього. Так звана «революційна романтика», яка була притаманна багатьом радянським теоретикам першої половини ХX століття, по суті виправдовувала будь-які засоби насилля й примусу людини у культурній та ідеологічній сферах заради формування щасливого майбутнього, цілеспрямовувала неухильно рухатися у фарватері політичних установок й директив влади. Елементи диктатури пролетаріату, які розглядалися як тимчасові міри, 
по суті поступово стали перманентними основами формування тоталітаризму. Позиція А. Луначарського та інших радянських теоретиків свідчила про певну ідеалізацію соціалістичної суспільно-економічної формації як кінцевого, найбільш досконалого результату розвитку людської цивілізації, а «диктатура пролетаріату» вбачалася як тимчасова й вимушена міра для встановлення ціннісних орієнтирів нового суспільства. Демократичні гасла щодо створення першого у світі народного суспільства, де немає експлуатації й насилля, несправедливості й аморальності, на жаль, маскували встановлення тоталітаризму в усіх сферах життєдіяльності та привели до втрати усіх демократичних начал культурних трансформацій суспільства. Культура стає ідеологічним механізмом по створенню демократичного за ознаками, але тоталітарного за змістом суспільства, який виступає основним регулятором суспільних відносин та підгрунтям для виховання людини нової формації.

Список використаних джерел

1. Луначарский А.В. Этюды политические и критические. М., 1906.175 с.

2. Луначарский А.В. Беседы по марксистскому миросозерцанию. М.: Рос. ин-т истории искусств, 1924. 85 с.

3. Луначарский А.В. Культурные задачи рабочего класса. Культура общечеловеческая и классовая. Петроград: Изд-во Союза Коммун Северной области, 1919. 24c.

4. Луначарский А.В. Культура в капиталистическую епоху. М.: Всероссийский Пролеткульт, 1923. 53 с.

5. Ленин В.И. Полное собрание сочинений. М.: Гос. изд-во политической литературы, 1950. Т.36. С.46.

6. Горбунов В.В. Разработка В.И. Лениным проблемы культурного наследия. М.: Знания, 1980. 518 с.

7. Шевцов Е.В. Основные средства и формы эстетического воспитания. Наследие А.В. Луначарского и современность. М.: Просвещение, 1985. 102 с.

8. Тимоти. Эдвард O’Коннор. Анатолий Луначарский и советская политика в области культуры. М.: Прогресс, 1992. 223 с.

9. Луначарский А.В. О народном образовании. М., Изд-во АПН РСФСР, 1958. С. 443-446.

10. Луначарский А.В. Против идеализма. Этюды полемические. М.: Работник Просвещения, 1924. 163 с.

References

1. Lunacharskij A.V. Etyudy politicheskie i kriticheskie. M., 1906. 175 s.

2. Lunacharskij A.V. Besedy po marksistskomu mirosozercaniyu. M.: Ros. in-t istorii iskusstv, 1924. $85 \mathrm{~s}$.

3. Lunacharskij A.V. Kulturnye zadachi rabochego klassa. kultura obshhechelovecheskaya i klassovaya. Petrograd: Izd-vo soyuza kommun severnoj oblasti, 1919. $24 \mathrm{~s}$.

4. Lunacharskij A.V. Kultura v kapitalisticheskuyu epoxu. M.: Vserossijskij proletkult, 1923. $53 \mathrm{s.}$

5. Lenin V.I. Polnoe sobranie sochinenij. M.: Gos. izd-vo politicheskoj literatury, 1950. T.36. S.46.

6. Gorbunov V.V. Razrabotka V.I leninym problemy kulturnogo naslediya. M.: Znaniya, 1980. 518 s.

7. Shevcov E.V. Osnovnye sredstva i formy esteticheskogo vospitaniya. nasledie A.V. Lunacharskogo i sovremennost. M.: Prosveshhenie, 1985. 102 s.

8. Timoti. Edvard o'Konnor. Anatolij Lunacharskij i sovetskaya politika v oblasti kultury. M.: Progress, 1992. $223 \mathrm{~s}$.

9. Lunacharskij A.V. O narodnom obrazovanii. M.: Izd-vo APN RSFSR, 1958. S. 443-446.

10. Lunacharskij A.V. Protiv idealizma. etyudy polemicheskie. M.: Rabotnik prosveshheniya, 1924. $163 \mathrm{~s}$. 


\title{
ФИЛОСОФСКИЕ ВЗГЛЯДЫ А.В. ЛУНАЧАРСКОГО НА ОБЩЕСТВЕННЫЕ ПРИОРИТЕТЫ В УСЛОВИЯХ КУЛЬТУРНЫХ ТРАНСФОРМАЦИЙ ПЕРВОЙ ПОЛОВИНЫ ХХ СТОЛЕТИЯ
}

\author{
И.Г. Мухина
}

В научной статье осуществлен анализ философских взглядов А.В. Луначарского на важные общественные приоритеты, которые возникают в условиях культурных трансформаций первой половины XX века на примере социального эксперимента большевиков во время «культурной революции» и в период создания так называемого пролетарского общества. Теоретик считал, что пролетариат в процессе исторической наследственности и при переходе к социалистической культуре должен играть исключительную и авангардную роль и быть законным наследником не только производственных сил, созданных в недрах буржуазного общества, но и наследником всех материальных и культурных ценностей.

Доказано, что содержание и сущность культурных трансформаций в период становления социалистического общества, способствовали формированию тоталитаризма на почве социальных мифов и революционной романтики. В целом, через призму философских размышлений А.В. Луначарского о влиянии культурных трансформаций на ценностные приоритеты общества, мы можем увидеть попытки большевиков создать корпоративную систему на социалистических началах, в которой большое внимание уделялось культурной и идеологической сферам, без которых невозможно создать действенные механизмы для управления и руководства обществом и выработать социальный миф о коммунистическом обществе как духовном ориентире человечества.

Акцентируется внимание на том, что так называемая «революционная романтика», которая была присуща многим советским теоретикам первой половины XX века, по сути оправдывала любые средства насилия и принуждения человека в культурной и идеологической сферах во имя формирования счастливого будущего, целенаправленно ориентировала на неуклонное движение в фарватере политических установок и директив власти. Доказано, что элементы диктатуры пролетариата, которые рассматривались как временные меры, по сути постепенно стали перманентными основами формирования тоталитаризма.

Ключевые слова: культурная революция, культурное наследие, ценности, культура, искусство, коллективизм, личность

\section{PHILOSOPHICAL VIEWS A.V. LUNACHARSKY ON SOCIAL PRIORITIES IN THE CONDITIONS OF CULTURAL TRANSFORMATIONS OF THE FIRST HALF OF THE 20TH CENTURY}

\author{
I.G. Mukhina
}

In the scientific article an analysis of the philosophical views of A.V. Lunacharsky concerning important social priorities that arise in the conditions of the cultural transformations of the first half of the twentieth century on the example of the social experiment of the Bolsheviks during the "cultural revolution" and in the period of the creation of the so-called proletarian society. The theorist believed that the proletariat, in the process of historical heredity and in the transition to socialist culture, should play an exclusive and avant-garde role and be a legitimate heir not only of the productive forces created in the depths of the bourgeois society, but also of the heir of all material and cultural values.

By defending collectivism as the basis of communist education, the philosopher claims that one must think, as "we," to become a living, useful, responsible body, part of this "we". But at the same time A. Lunacharsky warned that this upbringing did not lead to the appearance of "herding", complete degradation of the individual, loss of originality and individuality rights.

As a result of education in the personality, individual characteristics, talents, appropriate 
skills that people absorb and which society offers to them should be developed.

It has been proved that the content and essence of cultural transformations during the formation of a socialist society contributed to the formation of totalitarianism on the basis of social myths and revolutionary romanticism.

In general, through the prism of philosophical considerations, AV Lunacharsky, on the impact of cultural transformations on the values of society, we can see the attempts of the Bolsheviks to create a corporate system on a socialist basis, in which much attention was paid to the cultural and ideological spheres, without which it was impossible to create effective mechanisms for the management and management of society and to develop a social myth about the communist society as the spiritual reference point of mankind.

The emphasis is placed on the fact that the so-called "revolutionary romanticism", which was inherent in many Soviet theorists of the first half of the twentieth century, essentially justified any means of violence and coercion of man in the cultural and ideological spheres in order to form a happy future, aimed at steadily moving in the fairway political attitudes and directives of the authorities. It is proved that the elements of the dictatorship of the proletariat, which were regarded as temporary measures, have gradually become the permanent basis for the formation of totalitarianism.

Keywords: cultural revolution, cultural heritage, values, culture, art, collectivism, personality 